Article

\title{
The Ubiquitous-Eco-City of Songdo: An Urban Systems Perspective on South Korea's Green City Approach
}

\author{
Paul D. Mullins \\ The Bartlett Centre for Advanced Spatial Analysis, University College London, London, W1T 4TJ, UK; \\ E-Mail: paul.mullins.15@ucl.ac.uk
}

Submitted: 2 March 2017 | Accepted: 2 June 2017 | Published: 29 June 2017

\begin{abstract}
Since the 1980s, within the broader context of studies on smart cities, there has been a growing body of academic research on networked cities and "computable cities" by authors including Manuel Castells (Castells, 1989; Castells \& Cardoso, 2005), William Mitchell (1995), Michael Batty (2005, 2013), and Rob Kitchin (2011). Over the last decade, governments in Asia have displayed an appetite and commitment to construct large scale city developments from scratch-one of the most infamous being the smart entrepreneurial city of Songdo, South Korea. Using Songdo as a case study, this paper will examine, from an urban systems perspective, some of the challenges of using a green-city model led by networked technology. More specifically, this study intends to add to the growing body of smart city literature by using an external global eventthe global financial crisis in 2008-to reveal what is missing from the smart city narrative in Songdo. The paper will use the definition of an urban system and internal subsystems by Bertuglia et al. (1987) and Bertuglia, Clarke and Wilson (1994) to reveal the sensitivity and resilience of a predetermined smart city narrative. For instance, what happens if the vision moves from the originally intended international-orientated population towards remarketing the city to attract a domestic middle-class population. The lens of the financial crisis in 2008 revealed that the inherent inflexibility of a closed-system approach in Songdo was not sufficiently resilient to external shocks. The shift towards a domestic middle-class population revealed the inequality in accessing the city services in a system designed with formalized and rigid inputs and outputs. By focusing predominantly on technology, the social dimensions of the city were not part of Songdo's smart city vocabulary. Therefore, in adopting a technologically deterministic approach (Mullins \& Shwayri, 2016) to achieving efficiency and combating environmental issues, Songdo's green city model was found insufficient in its ability to cope with the complexity and dissonance that occurs in relation to "glocal" challenges facing cities today.
\end{abstract}

\section{Keywords}

eco-cities; Free Economic Zones; green city; smart city; Songdo; South Korea; sustainability; ubiquitous; urban systems

\section{Issue}

This article is part of the issue "Smart Cities-Infrastructure and Information", edited by Soora Rasouli, Harry Timmermans and Dujuan Yang (Eindhoven University of Technology, The Netherlands).

(C) 2017 by the author; licensee Cogitatio (Lisbon, Portugal). This article is licensed under a Creative Commons Attribution 4.0 International License (CC BY).

\section{Introduction}

Over the last decade, governments in Asia have displayed an appetite and commitment to construct large scale city developments from scratch-one of the most famous being the smart entrepreneurial city of Songdo, South Korea. As noted by Mullins and Shwayri, "these twentyfirst-century cities have been heralded as archetypal urban developments, owing to their focus on energy efficiency and low carbon emissions" (Mullins \& Shwayri,
2016 , p. 47). The global concern of climate change has re-conceptualized these new cities to address environmental concerns-such as carbon emissions to become "green" or "eco". As Federico Caprotti notes (2014, p. 8), the building of eco-cities is now at the "forefront of national and global agendas".

These newly-planned green cities all share the common approach to constructing urban systems based on low-carbon infrastructure (water recycling and automated collection systems), reducing and managing en- 
ergy consumption (LEED certified buildings, photovoltaic power and thermal cooling), as well as securing land (30\%) for green spaces to absorb carbon emissions. In this approach, it is the eminence of "harnessing technologies, including ICT" which has led to these green cities being classified under the more globally used umbrella term "smart" (Albino, Berardi, \& Dangelico, 2015, p. 4). The use of the term "smart" in relation to cities has become particularly problematic due to its many "conceptual variants" and inconsistencies, as demonstrated by scholars Albino et al. (2015), and O'Grady and O'Hare (2012). However, in the Korean context, the terminology privileged by both private and public sectors has been "ubiquitous", and, as such, the " $U$ " prefix has been readily adopted (U-Cities, U-Eco-City). The Ministry of Information and Communication in Korea define "Ubiquitous technologies" as "technology that allows everything around us to be networked for communicating with each other anytime and anywhere" (Ministry of Information and Communication, 2004, p. 4).

In Korea, as highlighted by Mullins and Shwayri (2016), the eco- or green-city approach to urban development has "become synonymous with the ubiquitous city concept and has been well-documented in recent scholarly discourse" (Mullins \& Shwayri, 2016, p. 49). For instance, examining the Korean ubiquitous eco-city (Kim, Kim, Moon, \& Bae, 2009), test-bed urbanism (Halpern, LeCavalier, Calvillo, \& Pietsch, 2013), and the politics of developing the eco-city model in the case of Songdo (Shwayri, 2013). In the broader context of studies on smart cities, since the 1980 s, there has also been a growing body of academic research on networked cities and "computable cities" by authors including Manuel Castells
(1989), Michael Batty (1995), William Mitchell (1995), and Rob Kitchin (2011).

Using Songdo as a case study, this research will examine, from an urban systems perspective, some of the challenges of using a green-city model led by networked technology. A mixture of primary and secondary sources based on the authors first-hand experience of the city and geographical and cultural context were utilized to interrogate the urban system and internal subsystems in relation to Songdo. More specifically, this paper aims to add to the growing body of smart city literature by using an external global event-the global financial crisis in 2008-to reveal what is missing from the smart city narrative in Songdo. Using the definition of an urban system and internal subsystems by Bertuglia, Clarke, and Wilson (1994), I intend to reveal the sensitivity and resilience of a predetermined smart city narrative. To address these questions, the first step will be to understand what is meant by, and what constitutes, an urban system.

\section{Defining Urban Systems}

In this paper, an urban system will be defined as "a set of elements known as subsystems, that interact with each other through socio-economic and spatial mechanisms" (Bertuglia et al., 1994, p. 84). The subsystems identified by Bertuglia et al. include: Housing Market, Job Market, Service Sector, Land Market and Transport.

As shown in Figure 1, the main subsystems that constitute an overall urban system are complemented by what Bertuglia et al. call the "corresponding variables for describing the structure of an urban system," and are as follows: population, housing stock, industry, services,

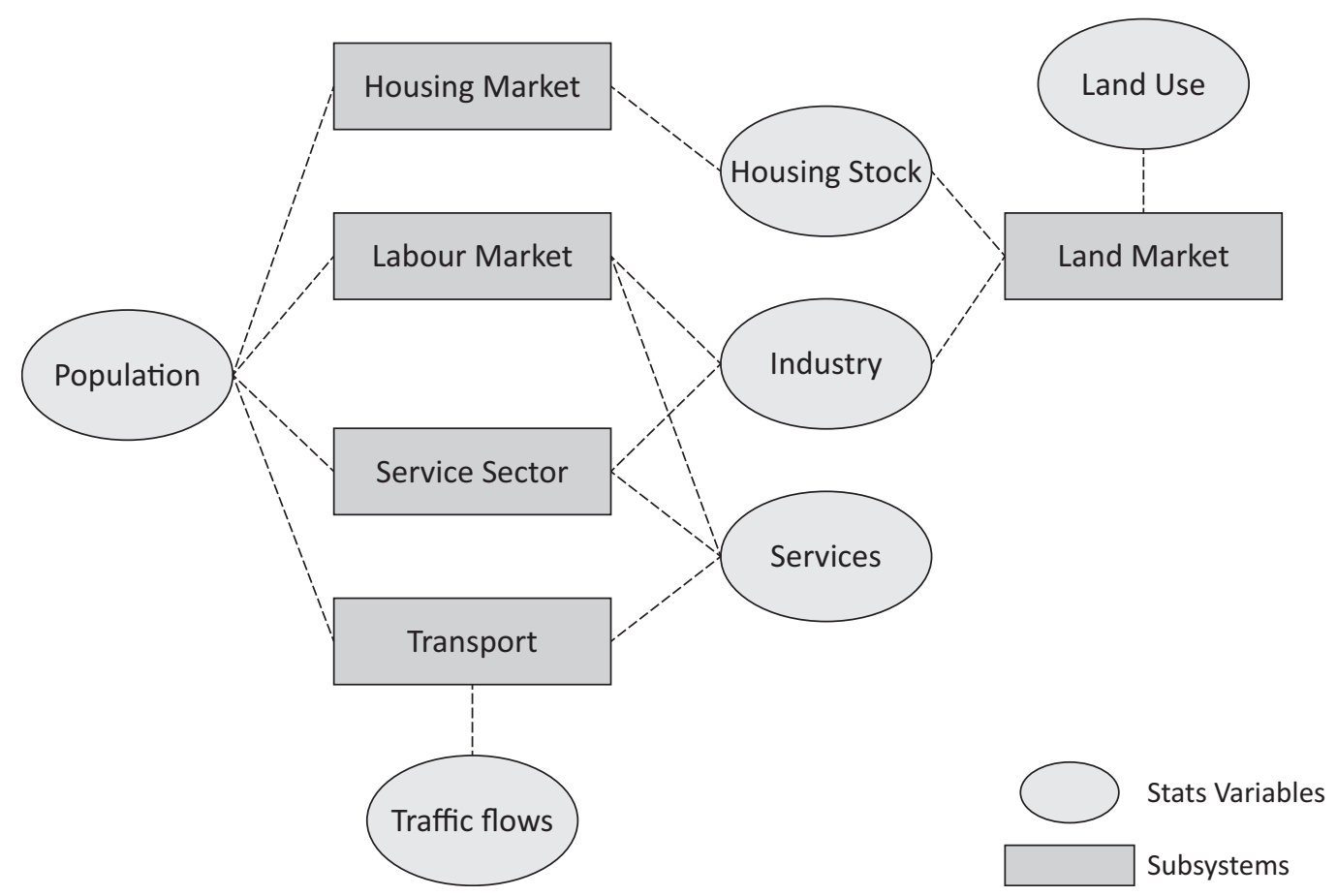

Figure 1. Urban system diagram of subsystems and corresponding variables. Source: Bertuglia et al. (1987, 1994). 
land use, and traffic flows. From this diagram, a number of assumptions can be drawn: firstly, that subsystems are considered as separate entities; secondly, that corresponding variables play a vital role in their interrelations between all subsystems, and that interconnectivity occurs throughout the whole urban system; thirdly, that each singular subsystem is dependent/reliant on multiple relations between corresponding variables. Population is one of the most active variables when there are multiple variable interaction relations (as seen in Table 1) according to Bertuglia et al. (1987, 1994).

Although, what is not revealed by the diagram in Figure 1 or Table 1 is the influence of external forces or shocks on the interconnecting variables and subsystems themselves. As Tzaka, Kalogirou, Papakostas and Symeonidou (2010, p. 108) argue, "Urban systems, within and between contemporary cities, are driven by the dynamics of global economy, politics, climatic change, advanced technologies and increased mobility".

\section{Ubiquitous-Eco-City of Songdo}

Songdo, along with Cheongna and Yeongjong, were part of a vision to create a transnational space, Incheon Free Economic Zone (hereafter IFEZ). IFEZ, which is overseen by the Incheon Free Economic Zone Authority (IFEZA), established in 2002, was intended to be a new hub for the
North-East-Asian regional economy to compete with established metropolises in the region, such as Singapore and Hong Kong (Figure 2). According to Sofia T. Shwayri (2013), the primary role of IFEZA, as the local authority charged with managing Songdo, was to court foreign investment and private partnerships to expedite the city from the concept stage to the reality of a twenty-first century global hub.

What is unusual about Songdo is that unlike any other Korean city it is managed by IFEZA, a governmental authority, but is $100 \%$ privately owned and funded. What makes this venture unique for Korea is that it is majorityowned by "foreign" companies. Gale International (hereafter Gale) owns a $60 \%$ share of the project, and the remaining proprietorship belongs to Morgan Stanley Real Estate $(9 \%)$ and the large Korean steel company POSCO (30\%). Songdo is also unusual in another respect, unlike earlier utopian visions of newly-planned cities, it was not envisioned as a response to the perils of overcrowding, as in the case of E. Howard and late-nineteenthcentury Garden City movement following the industrial revolution. In a recent paper by Ayyoob Sharifi (2016), which traced the evolution of twentieth-century planning movements from the Garden City to Eco-Urbanism, prominent "urban visionaries" - from Ebenezer Howard to Lewis Mumford and Patrick Geddes-are viewed as motivated not only to address social problems (such as

Table 1. Urban systems variables reliance and relations table (Bertuglia et al., 1987, 1994).

\begin{tabular}{lll}
\hline \multicolumn{2}{c}{ Urban System } \\
\hline Subsystems & Subsystem Variable Reliance \& Relations & Outcomes (Phenomena) \\
\hline Labour Market & $\begin{array}{l}\text { Population (supply) and Industries and } \\
\text { Services (demand) }\end{array}$ & Service Location Dynamics \\
\hline Service Sector & Population (supply) and Industries and & Service Location Dynamics \\
\hline Transport & Services (demand) & \\
& Population, Industrial and Service activities & Journeys to work, journeys to services, \\
& & commodity flows, modal demand and network
\end{tabular}

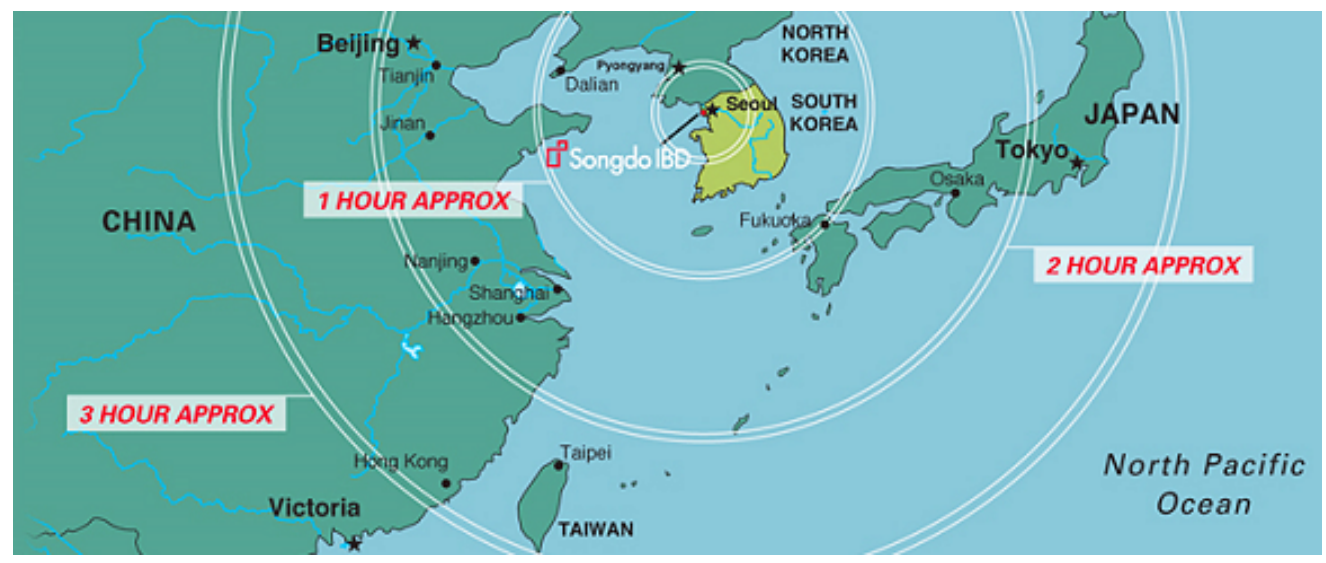

Figure 2. Location Map of Songdo (Songdo IBD from 2015), South Korea. Source: Gale International (2015). 
housing shortages through constructing new planned communities), but also to create social reform (Sharifi, 2016, p. 4).

It has been well-documented that the Korean population will peak between 2020 and 2030, and, if low birth-rates continue, the population will reduce from 50 million to around 34 million according to lowest predictions. Thus, Songdo was not built to solve a housing crisis for the domestic population, but, rather, for global competiveness, foreign businesses and non-Koreans. A focus on global and foreign investors is central to Songdo's vision and underlined by the marketing strategy adopted by the cities developers Gale (Kim, 2010). This approach of focusing almost exclusively on external markets and investment is also reflected in the city layout through to the networked infrastructure, which Jung I. Kim argued is "anti-Korean" -"an imagined Euro-American urbanity distant from the existing urban characteristics of Seoul" (2014, p. 334). Indeed, the developers and IFEZ consciously decided to create a city that is collage of western cities; the main centrepiece of the city, central park, is inspired by New York City's Central Park. One of the key criticisms of Gale's design approach has been lack of attention to diverse social interests in favour of "aestheticizing the environment" and showcasing its infrastructure (Kim, 2014, p. 334).

Before 2008, the vision for Songdo was as a large scale Ubiquitous-City, marketed abroad as an international "city in box" by IFEZ as well as Gale (Shwayri, 2013). However, around 2008, a series of international eventssuch as the global financial crisis and the United Nations Climate Change Conference-meant that the vision for Songdo changed with a new political agenda for Green Growth. The global financial crisis meant that some buildings could no longer be built, and the level of anticipated foreign investment severely reduced. This forced IFEZ and its developers to adapt their original plan and focus on domestic markets.

2008 was also a time of great political change domestically in Korea, as President Lee Myun Bak's new government made significant changes to the previous administrative structure, which would directly shape the future direction of the ICT and Ubiquitous ICT growth strategies. This was also the year that Korea was invited to be part of the G20. Not content with being considered part of the global landscape, Korea, aimed to take on a leading international role. Indeed, global concerns about climate change in relation to the Kyoto Protocol and the designation of countries as either Annex I/II (Under Article 4.2 (g) of the Convention) and Non-Annex elevated Korea's position as an anomaly in the classification system to be viewed as "a reliable bridge between the advanced and developing nations" (Kalinowski \& Cho, 2012, p. 4). At the G8 Extended Summit in Japan (2008), President Lee declared that Korea would voluntarily commit to Green House Gas emission reduction. With the model's appeal seemingly beginning to wane (as indicated by a lack of foreign investment by 2008), these global events acted as a catalyst in adapting the existing " $U$ " model to satisfy the needs of foreign governments eager to find lowcarbon solutions.

The global crisis of climate change then became the basis for Korea's next phase of ICT initiatives. In August 2008, President Lee announced that "low carbon green growth" would be central to combatting global warming and the economic crisis. He stated that Green ICT initiatives would become the new paradigm for economic and social development in Korea. The existing U-City model was then subjected to greening tactics as part of the newly-established Green Growth vision and was transformed into the "U-Eco-City". In relation to Songdo, as Yeon Mee Kim et al. (2009, p. 927) have noted, the intention then shifted to create a "sustainable city in which city management technologies based on ubiquitous infrastructure and the ecological system" ultimately formed an environmentally friendly city. Ubiquitous technologies were seen as ideal tools for showcasing "green technologies" in managing cities' energy efficiencies. The manipulation of the U-City concept proved useful as an attractive solution at time of global crisis to create a "UEco-City in a box". This was especially true for the developing Non-Annex I countries mindful of the climate change agenda and related financial-aid conditions, but looking to build new developments.

Apart from the rebranding of the Songdo as an "EcoU-City" model, one of the most significant changes to impact the existing urban system in Songdo was the shift in target population. As discussed earlier, population in the urban system represents a significant variable in the systems structure due to its high level of interconnectivity within the urban system structure (subsystems and related variables). While the population projections appeared unchanged with a daytime commuting population of 300,000 and resident population of 253,000 (IFEZ, 2011), the demographic target had moved away from an overseas market to a domestic one. This shift would challenge the resilience of the overall system, as many facets of the physical networked infrastructure were already under construction.

With a need to coax local investment, domestic developers seized the opportunity to become a part of the new master plan for Songdo. From 2008, amongst the luxury LEED buildings that signified smart and future city living, apartments of the kind found throughout Korea, began to spring up where investment for empty parcels of land had fallen through. These residential apartments did not have the same LEED status as the intended and pre-2008 apartments and did not become part of Cisco's Smart+Connected framework-for marketing Songdo from 2009. To boost residential figures employees of one of the major shareholder companies, POSCO, were encouraged to take-up residency in Songdo. However, due to the apartments' high costs-some fifteen times the average annual household income in 2009 (Shin, 2009), Songdo was fast becoming a city for the wealthiest portion of Korean Society only. 
The services that wealthy Seoulites had come to expect became problematic in Songdo due to high apartment prices, and lack of culturally specific amenities and services. For instance, the change in demographic target caused an increase in the demand for Korean restaurants, informal wet markets, childcare centres, and hagwons (private tuition institutes). Specifically, in relation to restaurant-service-based jobs, workers cannot afford to live in Songdo and are forced to endure long commutes for low pay using a transport system that is currently underdeveloped. Certainly, the affordability of eco-urban projects is a major problem. This concern has been also evidenced by other authors, such as Federico Caprotti (2014) and Caprotti, Springer and Harmer (2015), in relation to the case study of Dongtan eco-city near Shanghai. Elizabeth Rapoport's work (2014), which is a critique of how the term "eco-city" has been used historically additionally asserts that "affordable housing should all be considered as part of an eco-city framework" (Rapoport, 2014, p. 138). Additionally, Songdo's infrastructure cannot accommodate the informal wet markets that are commonplace in Korean cities. Indeed, conceptually, such informal markets, which are traditional and historical, do not represent the type of flagship future city that IFEZ wishes to project to the world.

Perhaps the most extreme example of the city's inflexibility of the infrastructure is Songdo's pneumatic waste collection systems. The networked pneumatic waste collection system below the streets of Songdo is connected to every planned commercial and residential dwelling with a focus on efficiency and carbon emission reduction to eliminate the need for rubbish collection trucks. On the streets of Songdo, public waste bins are inaccessible to non-residents because, to access them, you must have an official resident key (seen in Figure 3 ). This explicit indicator of Songdo's closed system has also caused problems for residents, as one IFEZ official informed the author (as part of an unstructured interview), on a recent tour of Songdo, that most people forget them, which means that rubbish accumulates near the bins. The bins themselves are also designed at a height and setback from the paths in a way that alienates, and makes them inaccessible to, wheelchair users.

Another attempt to boost domestic residential numbers has been orchestrated in the education sector, by the construction of new international schools and university campuses (both domestics and international). Such an approach has not been without its regulatory challenges and restrictions. According to Sonn, Shin, and Park (in press), there is normally a $40 \%$ cap on domestic students being enrolled in international schools; for example, this is the case in Seoul. However, regulations were relaxed pertaining to international primary and secondary schools in Songdo, which has resulted in the establishment of international independent schools such as Chadwick and Dulwich College (the main international schools in Korea and most showcased in Songdo's marketing literature). This policy is unlikely to develop social diversity as it will attract students from wealthier backgrounds and skew the socio-economic status of the urban system.

In the case of universities, Sonn et al. observed that creating "a new Korean university is still forbidden, but a new campus of an existing Korean university is allowed" (Sonn et al., in press, p. 10). As of 2016, three existing Korean universities have established secondary campuses in Songdo: Incheon University, Incheon Catholic University, and Yonsei University. For instance, from 2013, Yonsei has made it compulsory for all first-year students to attend and live on the Songdo international campus (IFEZ, 2014). Despite an influx of students, a lack of amenities that students are typically accustom to in Seoul has

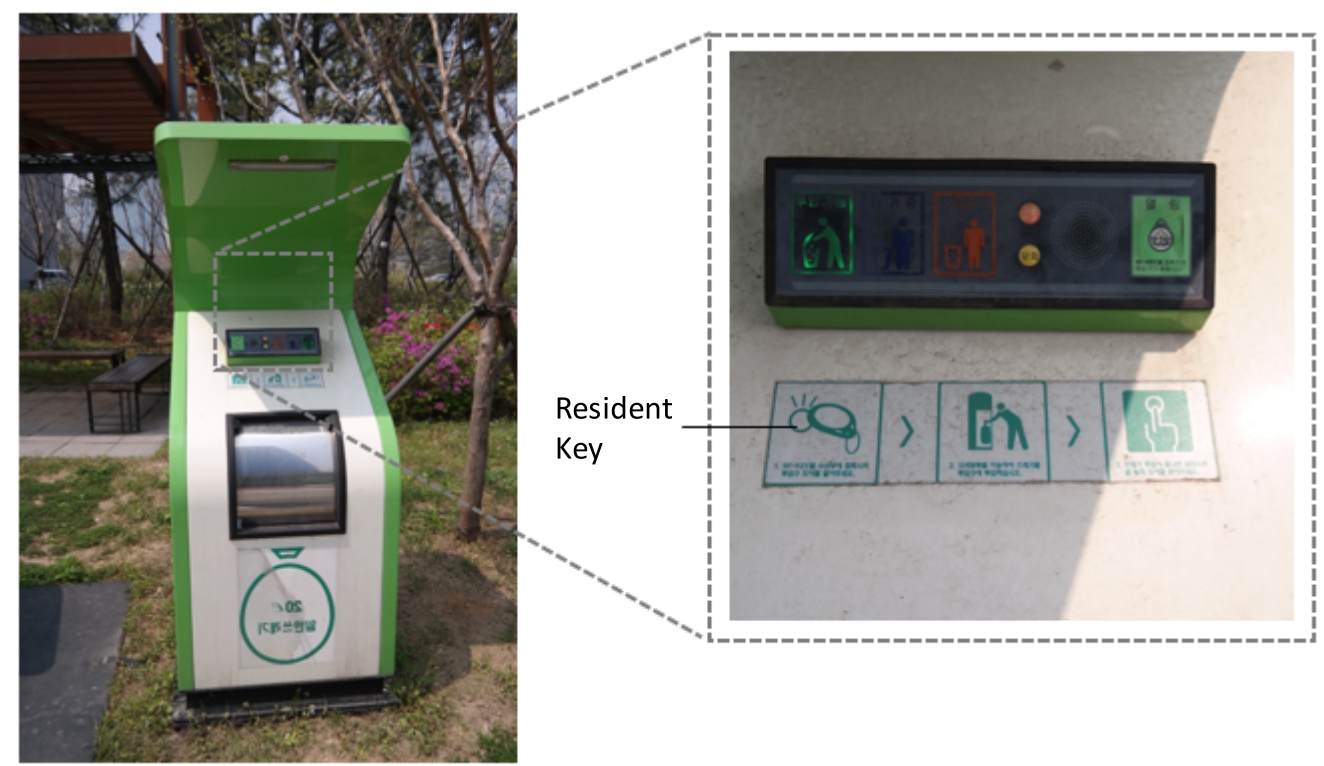

Figure 3. Photo of street-accessed waste bin system. Source: Author (20 February 2015). 
meant that many students have elected to commute daily or stay in Songdo only from Monday to Thursday. Furthermore, as the higher education system in Korea includes five months of vacation periods, the university campuses are empty for almost half the year.

International universities have also been building in Songdo. Four universities have opened international campuses. Of these, three are American-University of Utah, George Mason University, and SUNY Korea (The State University of New York)-and one Belgian, Ghent University is the first European university campus.

Thus, it is apparent that higher education and lowpaid jobs are some of the forces driving high numbers of domestic commuters who were unforeseen in the original model, which focused on international visitors. As the vision of a predominately international resident city diminishes, the inadequacy of transport has become increasingly apparent. For instance, the underground metro to Seoul takes around one and a half to two hours, and the route is via a change at Bupyeon Station in Incheon, as can be seen in Figure 4 . The express bus service does offer a direct route from Gangnam in the south- ern part of Seoul, but the commute still takes at least an hour's time. Indeed, as going by car is more direct (Figure 5) and a preferred mode of transport, traffic has increased as well as travel times. One of the more visible consequences of this phenomenon has been a steady increase in the number of new petrol stations on route from Seoul to Songdo since 2014, but notably not within the showcase area of Songdo's International Business District. On the streets of Songdo bike lanes have been downsized and absorbed into green spaces to widen the roads to accommodate increased car traffic. Like most districts in Seoul, Songdo offers extensive underground parking, which is said to make the city feel more pedestrian friendly; yet, with an increased road width and number of lanes, the city's master plan is less pedestrian friendly then originally intended.

\section{Technocratic Approach and Social Complexity}

One of the main problems found from administering a technocratic approach at a city scale, as in the case of Songdo, is the ability to cope with the challenges of so-

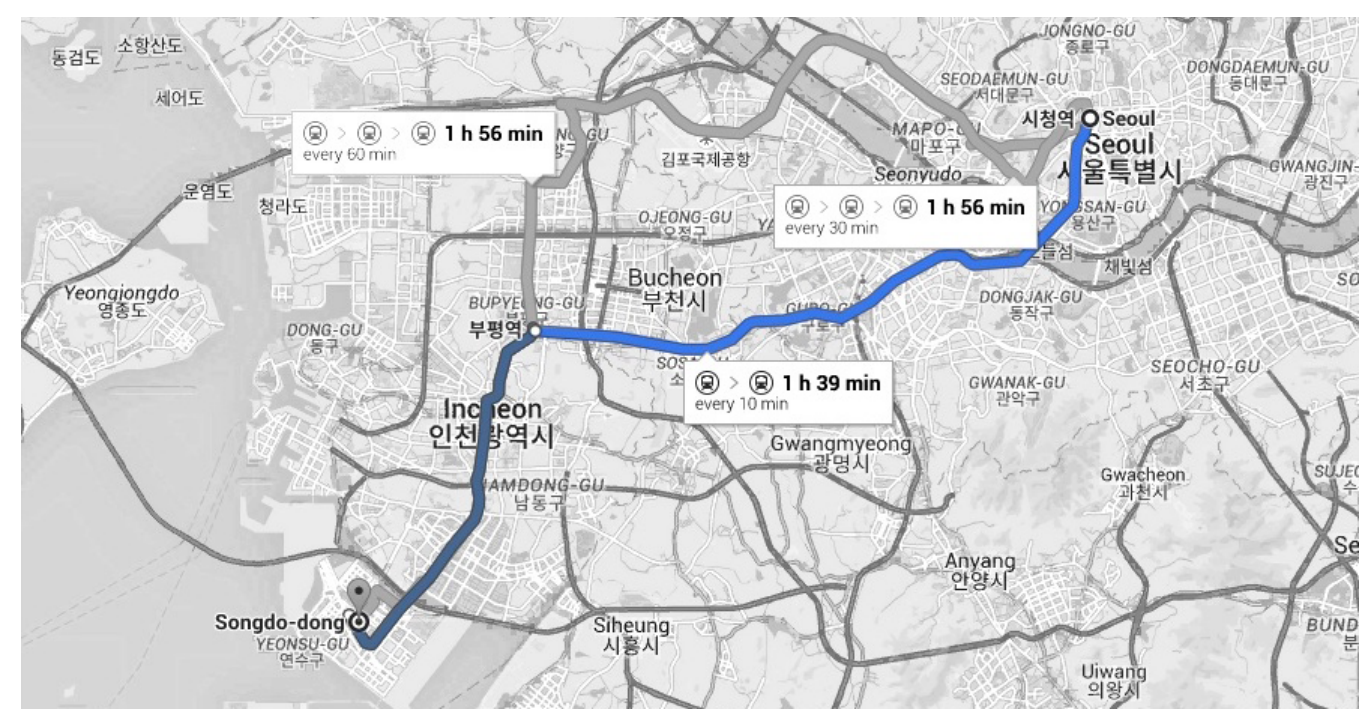

Figure 4. Commuting to Songdo by train. Source: Google Maps. Accessed December 2015.

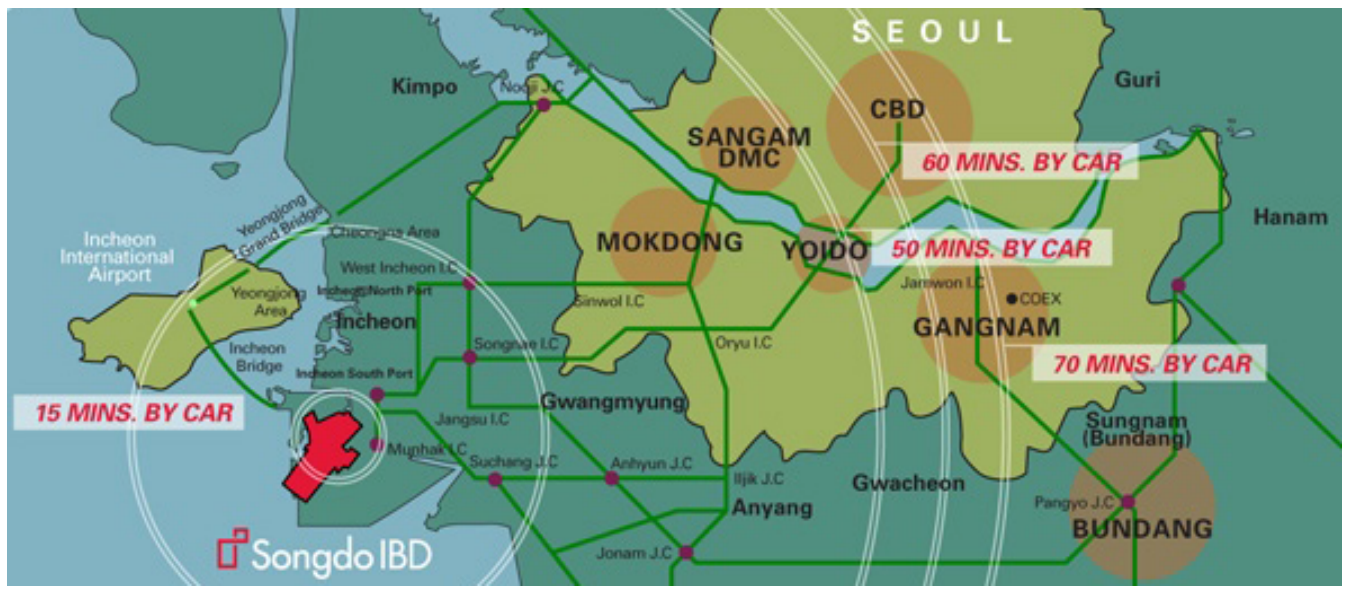

Figure 5. Commuting to Songdo by car. Source: Gale International (2015). 
cial complexity. Although, the problem of addressing social complexity as part of an urban systems discourse is not a recent challenge and predates the current zeitgeist of smart cities. For instance, Ida R. Hoos's work on Systems Analysis in Social Policy, nearly half a century ago, noted that by adopting such an approach is to make "certain assumptions about the nature of the social problems and certain presumptions about the state of the art of systems techniques" (Hoos, 1969, p. 25). What is also implicit in such an approach according to Hoos is that the complexity of social systems can be "reduced to measurable, controllable units all of whose relationships are fully recognised, appreciated, and amenable to manipulation" (Hoos, 1969, p. 25). In reducing the complexity of social systems, a consideration of intangible factors is often overlooked, such as the role of cultural nuanced uses of space. However, such factors may not be recognized by the vocabulary of a city especially when the city is developed as part of a technology determined system.

In Songdo, the unintended demographic became the dominant population due to an unforeseen external global event. This event, not only disrupted the intended narrative of the city, but also brought to light the challenge of the citizens' role and the degree citizen agency afforded by the city developers (Gale), the technology vendors and IFEZ. In this sense, Songdo, rather than becoming the city of the future, as it was promised by its authors, was arguably repeating the same trajectory as past Modernist Utopia's such as Brasilia. In the case of Brasilia, for example, many commentators such as James Holston (1989) and Margit Mayer (2011), noted that although the main physical structure of the city reflected the planners original model of looking futuristic, "from a sociological and organization perspective, the way commerce was organized had more in common with medieval London" (Dills \& Romiszowski, 1997, p. 26). It should be noted that, in the Korean context, such issues are not limited to cities built from scratch. For instance, along Tehran Ro, one of the main commercial streets in Gangnam, Seoul, there exists ongoing conflict between the traditional street vendors and the local authorities, who wish to sanitize the informal and culturally nuanced uses of space.

\section{Conclusions}

In a recent study, Mullins and Shwayri traced the evolution of Korea's green city paradigm and revealed how, "selling the U-City model was prioritized over a fully realized or conceptualized U-City model" (Mullins \& Shwayri, 2016, p. 61). By examining Songdo from an urban systems perspective, this paper intended to unpack some of the challenges of using a green-city model-led and characterized by the same networked-technology that it is trying to showcase. The lens of the global financial crisis in 2008 revealed that the urban system in Songdo was not flexible and formulated as a closed system which underappreciated the impact of fluctuations and vari- ability of external market forces. Unlike the cities that Songdo was supposed to rival-such as Hong Kong and Singapore-the closed system approach was constrained by a static conception of the role of foreign/local actors and relationship with the global markets. As Richard Sennet notes in his essay The Open City: Closed System: The Brittle City, "a closed system is meant to be integrated," and anything that wasn't part of the overall design is rejected or not registered by the system (Sennett, 2006). With a technologically deterministic approach to achieving efficiency and combating environmental issues, the U-City/U-Eco-City models are less sustainable in their in ability to cope with complexity. In relation to the latter, a closed urban system approach does not allow for the kind of "bottom-up" approach and citizen agency championed by early city commentators, such as Jane Jacobs and, more recently, in relation to the science of cities, Mike Batty. In the case of Songdo, and indeed for any new city built from scratch, an open system approach that is adaptable, can re-act and integrate non-intended inputs would be more resilient. Although Songdo is often considered unique as a case study by many scholars and commentators, the knowledge gained though this researchexamining the adoption of a "closed system" approachis transferable and, indeed, valuable to new cities and existing ones revising legacy infrastructure with smart city ambitions.

This paper has revealed how the whole urban system became vulnerable when one of the variables (population) diverted from the original plan. This deviation was against its developers and IFEZA's original model's that were intended for overseas markets. The shift towards a majority wealthy Korean domestic market has also revealed socio-spatial disparity, as well as inequality in accessing the city services in a system designed for formal inputs and outputs. Deregulation of educational policies, specifically in relation to international schools further compound the challenges of the urban system by only being accessible to the wealthiest members of Korean society. What this also revealed is how the change in population variable highlighted the shortcomings of the Songdo model. For instance, the individual subsystemsthat constitute the whole urban system-were conceptualized through a technology-first approach, and, consequently, found insufficient in their ability to cope with the complexity and transience of "glocal" challenges facing cities today. The central focus of technology as the dominant vocabulary has obscured the attention required to address the social dimensions of a city and neglected the impact of external influences.

From an urban systems perspective, one of the recommendations of this study would be to identify local and culturally defined characteristics that could be used as a proxy to inform an empirical study on urban systems in Songdo. Future research would also benefit from a variable- or factor-led approach; such as a deeper examination of the role of informal socio-economic activities, as well as citizen agency. This shift in approach is 
intended to elucidate the impact on and variability of urban systems, and whether such phenomena are culturally nuanced by an indirect consideration of multiple case studies. In relation to the wider context, future research should consider the translation of global policies (such as those derived by the New Urban Agenda) into local and domestically nuanced policies. The qualitative approach of this research used a mixture of primary and secondary academic, government, NGO and private sector literature, as well as unstructured interviews, and first-hand experience of the city over a 5-year period. These materials were largely English-language sources and unstructured interviews. Thus, future research would benefit from a greater engagement with and inclusion of Korean language sources to provide a more rounded discourse.

In a forthcoming paper by Sonn et al. (in press), we are reminded that Free Economic Zones in South Korea can be traced back to the 1970s and that these were essentially seen as "export-processing zones" (Sonn et al., in press, p. 8) until the financial crisis of 1997. According to Soon et al., after 1997, there was a conceptual shift towards viewing these zones as "a symbol of deregulation." From recent research by Mullins and Shwayri (2016), it evident that in the case of IFEZ, Songdo is less an example of deregulation in the era of "Smart," but, rather, a twenty-first century reconfiguration of "exportprocessing zones," which showcases technology for export. Therefore, based on the research from this study, for Songdo to achieve its target of low carbon emissions, IFEZ will need to adopt a strategy that is sympathetic to both conceptions of Free Economic Zones to navigate between the changing domestic political climate as well as adaptable to global market shifts.

\section{Acknowledgments}

This work was supported by a research grant from the MacArthur Foundation for a project examining the translation of new digital tools and technologies for practical applications in cities at The Bartlett Centre for Advanced Spatial Analysis (CASA).

\section{Conflict of Interests}

The author declares no conflict of interests.

\section{References}

Albino, V., Berardi, U., \& Dangelico, R. M. (2015). Smart cities: Definitions, dimensions, performance, and initiatives. Journal of Urban Technology, 22(1), 3-21.

Batty, M. (2005). Cities and complexity: Understanding cities through cellular automata, agent-based models, and fractals. Cambridge, MA: MIT Press.

Batty, M. (2013). The new science of cities. Cambridge, MA: MIT Press.

Bertuglia, C. S., Clarke, G., \& Wilson, A. (1994). Modelling the city: Performance, policy and planning. London: Routledge.

Bertuglia, C. S., Leonardi, G., Occelli, S., Rabino, G. A., Tadei, R., \& Wilson, A. G. (1987). Urban systems: Contemporary approaches to modelling. London: CroomHelm.

Caprotti, F. (2014). Eco-cities and the transition to low carbon economies. London: Palgrave Macmillan.

Caprotti, F., Springer, C., \& Harmer, N. (2015). 'Eco' for whom? Envisioning eco-urbanism in the Sino-Singapore Tianjin eco-city, China. International Journal of Urban and Regional Research, 39(3), 495-517.

Castells, M. (1989). The informational city: Information technology, economic restructuring, and the urban regional process. Oxford: Blackwell.

Castells, M., \& Cardoso, G. (Eds.). (2005). The network society: From knowledge to policy. Washington, DC: Johns Hopkins Centre for Transatlantic Relations.

Gale International. (2015). Sustainable design at Songdo IBD (Gale International Press Kit). Retrieved from http://www.songdo.com/songdo-international-busi ness-district/whysongdo/sustainable-city.aspx

Halpern, O., LeCavalier, J., Calvillo, N., \& Pietsch, W. (2013). Test-bed urbanism. Public Culture, 25(2 70), 272-306.

Holston, J. (1989). The modernist city: An anthropological critique of Brasília. Chicago, IL: University of Chicago Press.

Hoos, I. R. (1969). Systems analysis in social policy: Critical review. Berkeley, CA: University of California Press.

Incheon Free Economic Zone. (2011). IFEZ Project 2011. Incheon: Public Relations Office of Incheon Free Economic Zone Authority.

Incheon Free Economic Zone. (2014). Universities. IFEZ Global Center. Retrieved from http://www.ifez.go. $\mathrm{kr} / \mathrm{global}$

Kalinowski, T., \& Cho, H. (2012). Korea's search for a global role between hard economic interests and soft power. The European Journal of Development Research, 24(2), 242-260.

$\mathrm{Kim}, \mathrm{C}$. (2010). Place promotion and symbolic characterization of New Songdo City, South Korea. Cities, 27(1), 13-19.

Kim, J. I. (2014). Making cities global: The new city development of Songdo, Yujiapu and Lingang. Planning Perspectives, 29(3), 329-356.

Kim, Y. M., Kim, H. S., Moon, S. Y., \& Bae, S. Y. (2009). Ubiquitous eco-city planning in Korea. A project for the realization of ecological city planning and ubiquitous network society. In M. Schrenk, V. V. Popovich, D. Engelke, \& P. Elisei (Eds.), REAL CORP 2009 Proceedings (925-930). Schwechat: Competence Center for Urban and Regional Planning.

Kitchin, R. (2011). The programmable city. Environment and Planning B: Planning and Design, 38(6), 945-951. 
Mayer, M. (2011). The "Right to the City" in urban social movements. In N. Brenner, P. Marcuse, \& M. Mayer (Eds.), Cities for people, not for profit: Critical urban theory and the Right to the City (pp. 63-85). London and New York: Routledge.

Ministry of Information and Communication. (2004). The road to $\$ 20,000 \mathrm{GDP} /$ capita: IT 839 strategy. Seoul: Ministry of Information and Communication Republic of Korea. Retrieved from http://www. unapcict.org/ecohub/resources/the-road-to-20-000gdp-capita-it-839-strategy

Mitchell, W. (1996). City of bits: Space, place and the infobahn. Cambridge, MA: MIT Press.

Mullins, P. D., \& Shwayri, S. T. (2016). Green cities and "IT839": A new paradigm for economic growth in South Korea. Journal of Urban Technology, 23(2), 47-64.

O'Grady, M., \& O'Hare, G. (2012). How smart is your city? Science, 335(6076), 1581-1582.

Rapoport, E. (2014). Utopian visions and real estate dreams: The eco-city past, present and future. Geography Compass, 8(2), 137-149.

Sennett, R. (2006). The open city. In Urban Age. London:
Cities Programme, London School of Economics and Political Science.

Sharifi, A. (2016). From garden city to eco-urbanism: The quest for sustainable neighborhood development. Sustainable Cities and Society, 20, 1-16.

Shin, D. H. (2009). Ubiquitous city: Urban technologies, urban infrastructure and urban informatics. Journal of Information Science, 35(5), 515-526.

Shwayri, S. T. (2013). A model Korean ubiquitous ecocity? The politics of making Songdo. Journal of Urban Technology, 20(1), 39-55.

Sonn, J. W., Shin, H., \& Park, S. (in press). A mega urban project and two competing accumulation strategies: negotiating discourses of the Songdo International City development. International Development Planning Review.

Tzaka, A., Kalogirou, N., Papakostas, G., \& Symeonidou, I. (2010). SKG IN_FLUX: An urban 'process-plan'. In Future Cities: ECAADE 2010: Proceedings of the 28th Conference on Education in Computer Aided Architectural Design in Europe, September 15-18, 2010, Zürich, Switzerland, ETH Zürich (p. 107). Zürich: vdf Hochschulverlag AG.

\section{About the Author}

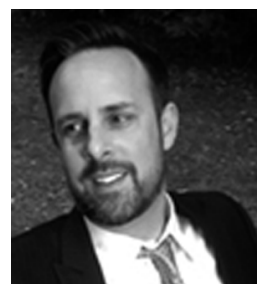

Paul D. Mullins is a Research Assistant at The Bartlett Centre for Advanced Spatial Analysis (CASA), UCL, working on a MacArthur Foundation-funded Applicable Urban Informatics project examining the translation of new digital tools and technologies for practical urban applications. Paul's research is concerned with spatial cultures and how new digital technologies can be used to make cities more equitable and inclusive. His interest in smart cities and the use of new technologies in the built environment emanates from his time spent in Seoul where he researched the development of the smart city concept and implementation in South Korea. 